\title{
The Role of Satisfaction in Mediating Compensation and Work and Environment against Employee Retention Pt. Senyum Media Utama Jember
}

\author{
${ }^{1}$ Kholid Ashari ${ }^{*}{ }^{2}$ Andi Sularso, ${ }^{3}$ Ika Barokah \\ ${ }^{1,2,3}$ Faculty of Economics and Business, University of Jember 37 Kalimantan Street, Jember 68132, \\ Indonesia
}

\begin{abstract}
Compensation is one form of efforts to reduce the high turnover of employees. Therefore, the presence of a good compensation, the employee will keep his job. And this is one form of motivation given the company's employee retention. Not only compensation that can affect employee retention. The work environment also affect employee retention. Any organization or company seeking better working conditions and satisfactory, so that employees in the work can feel satisfied with the work he did. The low turn over to the PT. Senyum Media Utama Jember indicate high commitment of its employees, but still there are employees who do not survive or out of the company although the amount is very minimal, so it needs to be tested how the compensation, organizational commitment and the work environment influence on satisfaction and retention. The population in this study were employees of PT. Senyum Media Utama Jember as much as 150 . The sample is observed is determined by purposive sampling method with the remaining number is 108. The analytical tool used is the analysis of SEM. Based on the analysis of the study results and discussion, it can be concluded that compensation, organizational commitment and the work environment influence on satisfaction and retention and satisfaction may mediate compensation, organizational commitment and work environment on employee retention. The observed sample is determined by purposive sampling method with the remaining number is 108 . The analytical tool used is the analysis of SEM. Based on the analysis of the study results and discussion, it can be concluded that compensation, organizational commitment and the work environment influence on satisfaction and retention and satisfaction may mediate compensation, organizational commitment and work environment on employee retention. The observed sample is determined by purposive sampling method with the remaining number is 108 . The analytical tool used is the analysis of SEM. Based on the analysis of the study results and discussion, it can be concluded that compensation, organizational commitment and the work environment influence on satisfaction and retention and satisfaction may mediate compensation, organizational commitment and work environment on employee retention.
\end{abstract}

Keywords: Compensation, Organizational Commitment, Work Environment, Satisfaction and Retention.

\section{Introduction}

Achievement of corporate objectives cannot be separated from the company's ability to manage human resources. HR is able to manage the company well to be maintained by the company that the retention. Employee retention is a method used by management to retain employees who have the competence to survive in the company to a specific period.

Retention is an attempt to maintain and improve the physical, mental, and also the attitude of employees in order to stay at home and generous in work so that organizational goals can be done well. With the effort or good retention strategy of an organization, the employee turnover or a process in which employees leave the organization can be minimized. According to Mathis and Jackson (2006: 126), the retention of employees is the company's ability to retain employees of the company's potential to remain loyal to the company. Employee retention can be maintained by providing compensation, commitment, work environment and job satisfaction felt by employees. 
Compensation is very important for employees as individuals, because wages are a measure of value or of their work among the employees themselves, their families and communities. Absolute income level employees who will determine the scale of life, and their relative income shows the status, dignity and value (Kreitner, Robert and Angelo Kanicki, 2016: 415).

Organizational commitment by Robins and Judge (2008: 100) is the degree to which a person favoring an organization's employees as well as the objectives and the desire to maintain membership in the organization. Thus, the involvement of a very high worker means favoring a particular job an individual, while the high organizational means favoring organizations that recruit such individuals. Employees who are committed to the organization then it will usually remain longer in the organization because they felt bound by the organization.

Davis and Newstrom (2008) explain that "Work condition relates to the scheduling of work-the length of work days and the time of day (or night) during the people work". Then, Schultz and Schultz (2010) explained that the environment or the working conditions are all physical aspects of the work, psychological working and work regulations which may affect job satisfaction and productivity.

According Luthans (2011), job satisfaction is a positive emotional state of a person arising from the appreciation of any work that has been done. It said further that job satisfaction is the result of one's achievement to how well his work providing something useful to him.

Some of the researchers who conducted research on the effect of compensation, the commitment, the working environment on job satisfaction and employee retention include Oktina et al (2015), found that compensation and working environment have a significant effect on job satisfaction and employee retention. But Anshori study (2018) showed that the working environment does not affect the retention of employees. Dhermawan (2012) also found that the work environment is not significant effect on satisfaction.

PT. Senyum Media Utama Jember is a company that offer a wide range of products of stationery and office supplies, computers, household appliances, cosmetics and others by applying the concept of self-service, wholesale and messages between the ministry. The Successful of PT. Senyum Media Utama Jember certainly not out of the performance of employees. PT. Senyum Media Utama Jember has a special attraction for the students who have graduated from college (undergraduate). Without hiring, there are 100 to 300 students and approximately 1,000 vocational graduates who apply each year. Other phenomena are PT. Senyum Media Utama Jember is a little amount of employee turnover.

Table 1: Permanent Employee Turnover PT. Senyum Media Utama Jember

\begin{tabular}{|c|c|c|c|c|c|}
\hline \multirow[b]{2}{*}{ Year } & \multicolumn{4}{|c|}{ Number of employees } & \multirow[b]{2}{*}{$\begin{array}{l}\text { turnover } \\
(\%)\end{array}$} \\
\hline & $\begin{array}{l}\text { Earlier } \\
\text { of the } \\
\text { year }\end{array}$ & entry & Exit & $\begin{array}{l}\text { End of } \\
\text { year }\end{array}$ & \\
\hline 2016 & 110 & 4 & 2 & 112 & 1.81 \\
\hline 2017 & 112 & 6 & 2 & 116 & 1.79 \\
\hline 2018 & 116 & 12 & 3 & 125 & 2.58 \\
\hline 2019 & 125 & 10 & 5 & 130 & 4 \\
\hline 2020 & 130 & 0 & - & 130 & 0 \\
\hline
\end{tabular}

Source: PT. Senyum Media Utama Jember

The overall number of employees of PT. Senyum Media Utama Jember is 150, and 20 people are employees of outsourcing, but the number of permanent employees is 130 people. Based on Table 1 indicate that PT. Senyum Media Utama Jember have low turnover. The number of permanent employees of PT. Senyum Media Utama Jember until 2020 amounted to 130 employees, the number of employees who come out until 2020 there were 12 employees out of a total of 32 coming in. The low turn over to the PT. Senyum Media Utama Jember indicate high commitment of its employees, but still there are employees who do not survive or out of the company although the amount is very minimal, so it needs to be tested how the compensation, organizational commitment and the work environment influence on satisfaction and retention. 


\section{Literature review}

\subsection{Effect of Compensation on Employee Satisfaction}

Compensation in the form of everything received by employees as remuneration for their work over the years. The compensation itself can be divided into two parts: compensation of direct and indirect compensation. And direct compensation to the employee remuneration is received directly, regularly or periodically, because he has been providing assistance / donations to achieve organizational goals (Ruky, 2001), and the direct compensation includes salary, bonus / incentive, commission. Indirect compensation includes holiday allowances, health benefits and performance benefits. Dhermawan (2012) in research proves that the compensation significant effect on employee satisfaction where the better the compensation received by an employee, it will be better the work satisfaction.

H1 : compensation significant direct effect on employee job satisfaction PT. Senyum Media Utama Jember

\subsection{Effect of Organizational Commitment on Job Satisfaction}

Organizational commitment can be defined as a belief and acceptance of the goals and values of the organization, a willingness to use earnest efforts for the benefit of the organization, a desire to maintain membership in the organization (Trisnaningsih, 2001). Organizational commitment and job satisfaction are two things that are often taken into consideration when assessing the change of accountants who work (Trisnaningsih, 2001). Fathonah and Utami (2011) found that organizational commitment and significant positive effect on job satisfaction of employees.

H2 : organizational commitment significant direct effect on employee job satisfaction PT. Senyum Media Utama Jember

\subsection{Effect of Work Environment on Employee Satisfaction}

Supportive work environment will affect job satisfaction and employee morale in work that is done, so the company must see to it that factors including the work environment can be cultivated in such a way and have a positive influence. Fathonah and Utami (2011) found that the working environment positive and significant effect on employee satisfaction Karanganyar District Secretariat. Furthermore Plangiten (2013) concluded that the work environment influence job satisfaction. Then Thus, improvements in the working environment, the employee satisfaction will be higher.

H3 : work environment significant direct effect on employee job satisfaction PT. Senyum Media Utama Jember

\subsection{Effect of Compensation on Employee Retention}

Real appreciation received by the employee is in the form of salaries, incentives and benefits. Many surveys show that one thing that is important to employee retention is to have compensation practices are competitive, or a payroll system that was based on several aspects as follows: (1) the payroll system to ensure fairness internally, (2) payroll system that can accommodate the influence of external factors , resulting in a balance, (3) payroll system to motivate employees, shaping the climate / culture of the company, supporting the organizational structure, and (4) payroll system to reflect the ability (financial) of a company or organization (Malthis and Jackson, 2006: 129 ). The conclusion is a competitive salary and benefits means to be "close" to what is provided by the company. Oktina,

H4 : compensation significant direct effect on the retention of employees of PT. Senyum Media Utama Jember

\subsection{Effect of Organizational Commitment on Employee Retention.}

Affective Commitment Relationship with Employee Retention in the previous studies suggest that there is a positive relationship. In the article explains that employees will be more committed to the company and also more committed to his supervisor if he felt that the supervisor will support the work (Shanock and Eisenberger, 2006). The literature supports the social and organizational culture shows that every time the subordinate correct and supported by the supervisor, this will yield positive results for both the company and employees (Shanock and Eisenberger, 2006). 
H5 : organizational commitment significant direct effect on the retention of employees of PT. Senyum Media Utama Jember.

\subsection{Environmental Influence against Employee Retention.}

Someone working environment within a particular institution can affect the desire to keep working on these institutions, or seek another company or institution as a place of work. Concrete examples of the work environment as well as non-physical work environment in the form of organizational climate, and organizational components and comfort in work. Holbeche (2005) explains that there are three impact produced by the organizational climate that impact on employee motivation, development and employee retention, and employee performance. Anshori (2018) found the work environment significant positive effect on employee retention.

H6 : work environment significant direct effect on the retention of employees of PT. Senyum Media Utama Jember.

\subsection{Effect of Satisfaction on Employee Retention.}

Job satisfaction is an important variable in the organization. It is based on three reasons as proposed by Spector (2003): First, job satisfaction can be a measuring tool effectiveness of measures taken by the company to the employee. Second, job satisfaction affects employee behavior that ultimately affect the smooth running of the company. Third, job satisfaction is an indicator of problems in the company because of the low level of job satisfaction showed irregularities in the department. Job satisfaction is high or both will make employees more loyal to the company or organization, and ultimately strive to provide the best for the organization. Thus it is clear that job satisfaction can affect employee retention. Oktina, et al (2018),

H7 : job satisfaction significant direct effect on the retention of employees of PT. Senyum Media Utama Jember.

\subsection{Effect of Compensation on Employee Retention Through Job Satisfaction}

The relationship between compensation and job satisfaction in a study that suggested that compensation has a positive relationship with job satisfaction (Hariandja, 2002). Proper compensation will stimulate morale and job satisfaction employees. Due to appropriate compensation gained from working will affect the job satisfaction of employees. Kumar et al., (2012) found a positive effect between compensation and employee retention. This study explains that employees will feel valued by the company if they get proper compensation; therefore, employees will be motivated and will work better for the company because they feel satisfied. Indirectly, employees tend to persist within companies.

H8 : compensation significant indirect effect on the retention of employees through the job satisfaction of employees of PT. Senyum Media Utama Jember

\subsection{Effect of Organizational Commitment on Employee Retention Through Job Satisfaction}

Retention program of employees have several factors that can affect the program, among them the organizational commitment, employer of choice perception, organizational climate, and a program of wellbeing of employees, it is shown by the relationship factors that influence the retention of employees (Roodt, 2005). Employee retention is influenced by several factors, such as employee orientation, career planning, employee relations, employee motivation, performance management, training and development, promotion, and compensation (Ratnasari, 2011). Employees who feel satisfied with everything that is provided by the company will persist longer in the company.

H9 : organizational commitment significant indirect effect on the retention of employees through the job satisfaction of employees of PT. Senyum Media Utama Jember

\subsection{Effect of Work Environment on Employee Retention through Job Satisfaction}

Supportive work environment will affect job satisfaction and employee morale in work that is done, so the company must see to it that factors including the work environment can be cultivated in such a way and have a positive influence. Baron and Rue (2007: 321) states that a good working environment will provide comfort and raise employee morale so that they can do the tasks well. In the end, the work environment can increase job satisfaction in the work. Holbeche (2005) explains that there are three impact produced by the 
organizational climate that impact on employee motivation, development and employee retention, and employee performance

H10 : work environment significant indirect effect on the retention of employees through the job satisfaction of employees of PT. Senyum Media Utama Jember.

\section{Methodology}

This research can be classified as explanatory research study. The population in this study were employees of PT. Senyum Media Utama Jember as much as 150 . The sample is observed is determined by purposive sampling method with the criterion is a). permanent employees in addition to the OB and guard (for OB and security is outsourced), and b) .karyawan who have worked at least 3 years. The sample has filled the questionnaire is as much as 108 people. The variables used in this study are the exogenous variables ie compensation, organizational commitment and work environment, namely intervening variables and variable endogennya satisfaction is retention.

\section{Results and Discussion}

\subsection{Results}

\section{a. Overview of Respondents}

Based on the results of data collection, data showed employees at PT. Senyum Media Utama Jember who completed questionnaires were 108 people, it can be seen a general idea about the age, education, past and length of employment.

\section{Table 2: Characteristics of Respondents by Age}

Source: Processed Data. 2020.

\begin{tabular}{|l|l|l|}
\hline No. & Age & Number of people) \\
\hline 1 & $20-29$ Years & 79 \\
\hline 2 & $30-39$ Years & 19 \\
\hline 3 & $40-49$ Years & 7 \\
\hline 4 & $>50$ Years & 3 \\
\hline & Last education & amount \\
\hline 1 & SMP & 1 \\
\hline 2 & SMK & 96 \\
\hline 3 & D3 & 5 \\
\hline 4 & S1 & 6 \\
\hline & Length of working & amount \\
\hline 1 & $3 \leq \mu<10$ years & 90 \\
\hline 2 & $\geq 10$ years & 18 \\
\hline
\end{tabular}

a. Based on Table 2, the majority of respondents by age characters are employees of PT. Senyum Media Utama Jember aged 20 to 29 years as many as 79 people, aged 30 to 39 years as many as 19 people. Employees aged 40 to 49 years there were 7 people and more than 50 years there were two people. The data shows that the majority of employees of PT. Senyum Media Utama Jember are employees who are in the productive age.

b. The majority of employees of PT. Senyum Media Utama Jember respondents by last education is as much as 96 vocational school, junior only one person, there are 5 people D3 and S1 graduate as many as six people. 
c. The majority of employees of PT. Senyum Media Utama Jember has worked for more than 3 years as many as 90 employees and employees who work more than 10 years as many as 18 people. This indicates that employees feel at home to work in the company.

\section{b. Model Test Results}

Having tested the validity and reliability on all latent variables that provide valid and reliable results, the data multivariate normal, did not happen multikolinieritas and there is no outlier, then the variable can be followed by a conformance test models and test the significance of causality compensation, organizational commitment, work environment, satisfaction employment and retention.

a. Conformance Test Model (Goodness of fit test)

Testing the model in SEM aims to see the suitability of the model with the data presented in Table 3.

Table 3: SEM Compliance Index

\begin{tabular}{|l|l|l|l|}
\hline Criteria & $\begin{array}{l}\text { Value Cut } \\
\text { Off }\end{array}$ & $\begin{array}{l}\text { The } \\
\text { calculation } \\
\text { results }\end{array}$ & $\begin{array}{l}\text { Informatio } \\
\mathrm{n}\end{array}$ \\
\hline $\begin{array}{l}\text { Chi } \\
\text { Square }\end{array}$ & $\begin{array}{l}\text { Expected to } \\
\text { be small } \\
(<\mathrm{X} 2 \text { with } \\
\mathrm{df}=39)\end{array}$ & $\begin{array}{l}48.321 \\
\text { Prob } \\
0.549\end{array}$ & Good \\
\hline $\begin{array}{l}\text { Sign. } \\
\text { probability }\end{array}$ & $\geq 0.05$ & .549 & Good \\
\hline RMSEA & $\leq 0.08$ & 0.078 & Good \\
\hline GFI & $\geq 0.90$ & 0.931 & Good \\
\hline AGFI & $\geq 0.90$ & 0.952 & Good \\
\hline $\begin{array}{l}\text { CMIN } / \\
\text { DF }\end{array}$ & $\leq 2$ or 3 & 1.239 & Good \\
\hline TLI & $\geq 0.95$ & 0,939 & marginal \\
\hline CFI & $\geq 0.95$ & .988 & Good \\
\hline
\end{tabular}

Source: Data processed, 2020

Based on Table 3 note that of the eight criteria used to assess whether or not a model turned out seven criteria are met, and is therefore said to be models to be accepted, which means there is a match between the model with data. The test results with the AMOS program provides the results of structural equation model that shows the relationship between latent variables as shown in Figure 1 


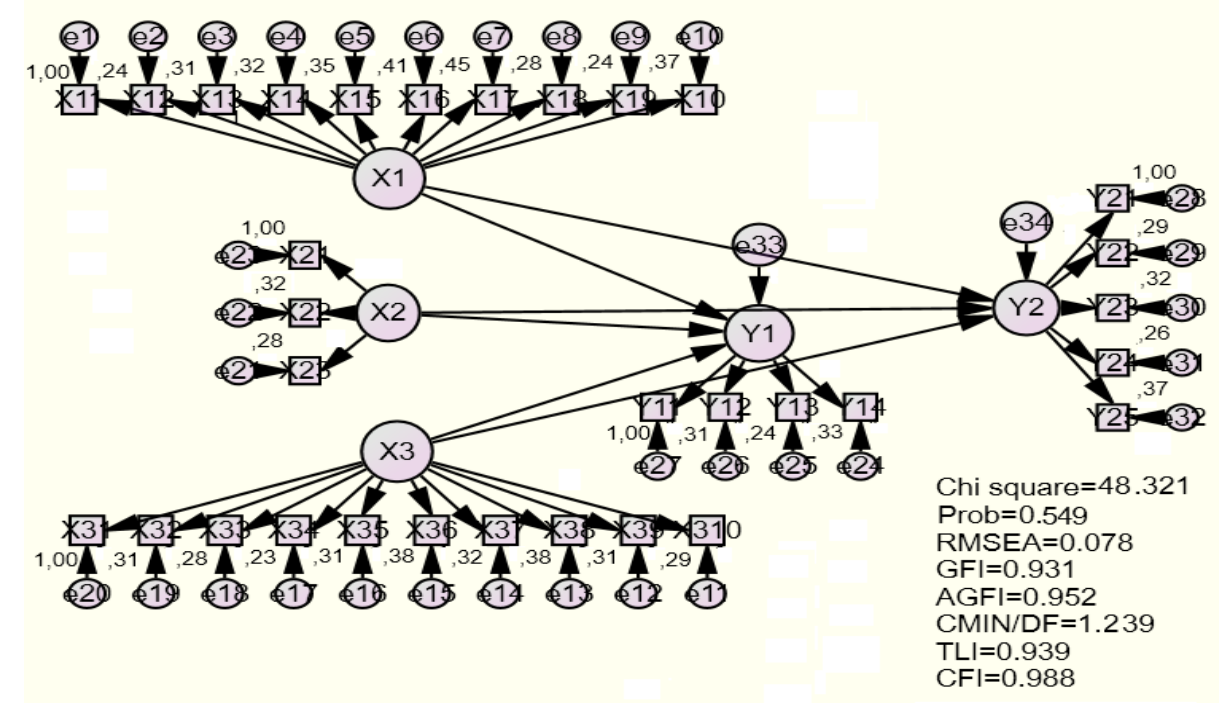

Figure 1: Effect of compensation, organizational commitment, work environment, job satisfaction and retention

Source: Data processed, 2020

b. Causality Test

After testing the suitability of the research model, the next step is to test the causality hypothesis developed in the research model. Detailed testing path coefficients are presented in Table 4.

Table 4: Results of Testing Causality

\begin{tabular}{|l|l|l|l|}
\hline variables & CR & Prob. & Information \\
\hline $\mathrm{X} 1 \rightarrow \mathrm{Y} 1$ & 3,337 & 0,002 & Significant \\
\hline$\rightarrow \mathrm{X} 1 \mathrm{Y} 2$ & 2,630 & 0,003 & Significant \\
\hline $\mathrm{X} 2 \rightarrow \mathrm{Y} 1$ & 3.396 & 0,003 & Significant \\
\hline $\mathrm{X} 2 \rightarrow \mathrm{Y} 1$ & 2.357 & 0,025 & Significant \\
\hline$\rightarrow \mathrm{X} 3 \mathrm{Y} 1$ & 2.490 & 0,036 & Significant \\
\hline$\rightarrow \mathrm{X} 3 \mathrm{Y} 1$ & 2,510 & 0,023 & Significant \\
\hline
\end{tabular}

Source: Data processed, 2020.

c. In Mediating Role of Compensation Satisfaction, Organizational Commitment and Working Environment Against Retention

Indirect relationship occurs between exogenous latent variables compensation, organizational commitment and work environment against endogenous latent variable retention through intervening latent variables namely satisfaction. Indirect relationships between variables can be seen from Table 5 .

Table 5: Pengaruh Indirect Variables

\begin{tabular}{|l|l|l|l|l|}
\hline \multicolumn{2}{|l|}{ Indirect effect } & \multicolumn{4}{|l|}{ Exogenous variables } \\
\cline { 3 - 5 } & $\mathrm{X} 1$ & $\mathrm{X} 2$ & $\mathrm{X} 3$ \\
\hline \multirow{2}{*}{$\begin{array}{l}\text { Endogenou } \\
\text { s variables }\end{array}$} & $\mathrm{Y} 1$ &, 000 &, 000 &, 000 \\
\cline { 2 - 5 } & $\mathrm{Y} 2$ &, 187 &, 141 &, 133 \\
\hline
\end{tabular}

Source: Data processed, 2020. 
The indirect effect:
1. $\mathrm{X} 1 \square \mathrm{Y} 1 \square \mathrm{Y} 2=0.187$
2. $\mathrm{X} 2 \square \mathrm{Y} 1 \square \mathrm{Y} 2=0.141$
3. $\mathrm{X} 3 \square \mathrm{Y} 1 \square \mathrm{Y} 2=0.133$

Based on Table 5 it can be seen that the indirect effect compensation, organizational commitment and the environment againstcustomer retention by $0.187 ; 0.141$; and 0.133 . The indirect effect is greatest compensation for retention through customer satisfaction.

\section{Discussion}

Effect of Compensation on Employee Satisfaction at the Office of PT. Senyum Media Utama Jember The analysis showed that the variable compensation significant positive effect on employee satisfaction in PT. Senyum Media Utama Jember, with a significance value less than 0.05 is 0.002 . So the first hypothesis which states that compensation is a significant direct effect on employee job satisfaction PT. Senyum Media Utama Jember, is accepted. This indicates that the better the compensation given by the company, the satisfaction will increase, and vice versa. The significant compensation on employee satisfaction in PT. Senyum Media Utama Jember evidenced by the number of employees who admit that PT. Senyum Media Utama Jember:
a. provide regular salary,
b. When the feast, gives THR to its employees.
c. provide a target bonus, if the employees work achieve the set targets,
d. provide periodic salary increases to employees,
e. give overtime pay, if the working hours exceed the hours of operations of the company,
f. involving employees in BPJS Kesehatan,
g. involving employees in BPJS Ketenagakerjaan,
h. hold annual tourist each year end,
i. provide maternity leave for employees who give birth,
j. Provide annual leave to employees.

The results are consistent with the theory put forward by Luthans (2015) states that "compensation is important for employees are as individuals, because wages constitute a form of value received by the employee on performance given to the company". Dhermawan (2012) in research proves that the compensation significant effect on employee satisfaction where the better the compensation received by an employee, it will be better the work satisfaction. Later research by Fathonah and Utami (2011) found that the Compensation positive and significant effect on employee satisfaction Karanganyar District Secretariat.

The implication is PT. Senyum Media Utama Jember expected to maintain and if able to increase the compensation to its employees equally and fairly. Compensation that will either create a positive perception for employees. Primarily related to employee satisfaction, because the company directly have to appreciate what has been doing for the company.

\section{Effect of Organizational Commitment on Job Satisfaction at the Office of PT. Senyum Media Utama Jember}

The analysis showed that the variables of organizational commitment significant positive effect on employee satisfaction in PT. Senyum Media Utama Jember, with a significance value less than 0.05 is 0.003 . So that the second hypothesis which states that a significant direct effect of organizational commitment on job satisfaction of employees of PT. Senyum Media Utama Jember, is accepted. This indicates that the better the organizational commitment owned by the employee, the job satisfaction will increase, and vice versa.

The significant organizational commitment to employee satisfaction at PT. Senyum Media Utama Jember evidenced by the number of employees who admit that PT. Senyum Media Utama Jember:

a. have an emotional bond with their employees, 
b. the workplace can bring benefits for employees,

c. a workplace that appreciates the loyalty of its employees.

Organizational commitment is the degree to which a person favoring an organization's employees as well as the objectives and the desire to maintain membership in the organization (Robins and Judge, 2008: 100). Thus, the involvement of a very high worker means favoring a particular job an individual, while the high organizational means favoring organizations that hire individuals. The results are consistent with research conducted by Fathonah and Utami (2011) who found that organizational commitment and significant positive effect on job satisfaction of employees. Organizational commitment and job satisfaction are two things that are often taken into consideration when assessing the change of accountants who work (Trisnaningsih, 2001).

The implication is PT. Senyum Media Utama Jember is expected to increase the emotional bond between employees and appreciate the work of employees so that employees have the organizational commitment and job satisfaction is able to produce. Companies can find out how much an employee is emotionally bound, familiar with and involved in the organization. Employees with a high affective commitment remain with the organization because they want to. These people know the organization and is bound to remain a member of the organization to achieve organizational goals. This commitment comes from the individual working conditions and expectations of the individual are fulfilled in the organization.

\section{Effect of Work Environment on Employee Satisfaction at the Office of PT. Senyum Media Utama Jember}

The analysis showed that the work environment variables significant positive effect on employee satisfaction in PT. Senyum Media Utama Jember, with a significance value less than 0.05 is 0.036 . So the third hypothesis which states that the work environment a significant direct effect on employee job satisfaction PT. Senyum Media Utama Jember, is accepted. This indicates that the better the work environment PT. Senyum Media Utama Jember, it will increase employee satisfaction, nor vice versa. Significant positive work environment on employee satisfaction in PT. Senyum Media Utama Jember evidenced by the number of employees who admit that PT. Senyum Media Utama Jember:
a. decent location,
b. have a place of worship for the employees,
c. has a special room for rest of employees,
d. have a special parking lot employee,
e. provide office facilities for employee vehicles,
f. secure environment,
g. comfortable environment,
h. provide training to its employees,
i. have a sense of kinship,
j. Always given a religious spirit.

Baron and Rue (2007: 321) states that "a good working environment will provide comfort and raise employee morale so that they can do the tasks well". Fathonah and Utami (2011) found that the working environment positive and significant effect on employee satisfaction Karanganyar District Secretariat. Furthermore Plangiten (2013) concluded that the work environment influence job satisfaction. Then thus, improvements in the working environment, the employee satisfaction will be higher

The implication is PT. Senyum Media Utama Jember is expected to maintain a work environment that has been able to facilitate their employees to work so that they feel comfortable and safe. If the working environment is good, then it can spur the emergence of self-satisfaction in employees, which in turn can have a positive influence on job satisfaction of employees, and vice versa if the working conditions are bad, the employee will not have job satisfaction in the work. 


\section{Effect of Compensation on Employee Retention at the Office of PT. Senyum Media Utama Jember}

The analysis showed that the variable compensation significant positive effect on retention of employees at PT. Senyum Media Utama Jember, with a significance value less than 0.05 is 0.003 . So that the fourth hypothesis which states that the compensation significant direct effect on the retention of employees of PT. Senyum Media Utama Jember, is accepted. This indicates that the better the compensation given by the company, the company does not need to perform retention, because employees have been loyal.

Compensation influential on the retention of employees at PT. Senyum Media Utama Jember evidenced by the number of employeesrecognizes that with given compensation in the form of salaries, THR, target bonus, periodic salary increases, overtime, BPJS Kesehatan, BPJS Ketenagakerjaan, the annual tourist each year end, maternity leave and annual leave to employees, many employees last worked at PT. Senyum Media Utama Jember. In addition, the employee last worked in PT. Senyum Media Utama Jember because:

a. cultural works have a positive impact,

b. the company provides training to develop the potential,

c. Companies appreciate the achievements of its employees,

d. the flexible nature of the job

e. relationship between employees and leadership intertwined harmoniously.

Competitive salary and benefits means to be "close" to what is provided by the company and what is believed by the employees in accordance with the capabilities, experience and performance (Malthis and Jackson, 2006: 129). Oktina, et al (2018) found that compensation significantly influence employee retention. Marina (2018), found that high compensation will increase employee retention. Son et al (2018), found that compensation positive effect on retention. This shows that the higher the level of compensation the higher the level of employee retention.

The implication is PT. Senyum Media Utama Jember expected to maintain the compensation that has been given, it may even increase their compensation compensation either directly or indirectly. Companies can also provide benefits program that can be seen as an opportunity for employees. For example, payment of tuition fees if the employee is an employee who excel.

\section{Effect of Organizational Commitment on Employee Retention at the Office of PT. Senyum Media Utama Jember}

The test results showed that the variables of organizational commitment significant positive effect on retention of employees at PT. Senyum Media Utama Jember, with a significance value less than 0.05 is 0.025 . So the fifth hypothesis which states that the organizational commitment of significant direct effect on the retention of employees of PT. Senyum Media Utama Jember, is accepted. The results showed that the better the organizational commitment shown by the company, the employee retention, the better, nor vice versa.

Relationship commitment to employee retention in the previous studies suggest that there is a positive relationship. In the article explains that employees will be more committed to the company and also more committed to his supervisor if he felt that the supervisor will support the work (Shanock and Eisenberger, 2006). The literature supports the social and organizational culture shows that every time the subordinate correct and supported by the supervisor, this will yield positive results for both the company and employees (Shanock and Eisenberger, 2006). The results showed that the majority of employees feel that PT. Senyum Media Utama Jember have an emotional bond with its employees, the company generates revenue for its employees, and a workplace that appreciates the loyalty of its employees,

Organizations that have a culture and a positive value and a different experience lower employee turnover. Organizational culture is a pattern of shared values and beliefs that give meaning and rules of behavior for organizational members. The main organizational value that affects the employee's desire to survive is trust.

The implication is PT. Senyum Media Utama Jember can maintain and increase the confidence of employees to stay afloat so that they have a feeling of obligation to remain in the organization. Companies can ensure fairness company by having a comprehensive grievance procedures, providing extensive 
bidirectional communication. Companies can also create a sense of community by establishing homogeneity based on value, fairness, emphasizing teamwork, mutual support, and teamwork, coming together

\section{Environmental Influence Against Employee Retention at the Office of PT. Senyum Media Utama Jember}

The test results show that the environment variable significant positive effect on retention of employees at PT. Senyum Media Utama Jember, with a significance value less than 0.05 is 0.023 . So the sixth hypothesis which states that the work environment a significant direct effect on the retention of employees of PT. Senyum Media Utama Jember, is accepted. The results showed that the better the company's work environment, then the retention will increase. Conversely, if the work environment is getting worse, then the retention will decrease. Working conditions certainly play an important role against both the poor quality of employee performance. If the working environment is quite convenient and communication among members of the team run smoothly, then certainly the resulting performance will certainly maximized. But on the contrary,

Luthans (2015) states that, in addition to compensation, as for the working environment factors can also influence whether or not the employee convenient to survive in an organization. The results are consistent with research Oktina, et al (2018), found that the work environment directly affects employee retention Indonesian Red Cross in Aceh province. Son et al (2018), found that environmental crimes positive effect on retention. This study is not in line with research conducted by Anshori (2018) who found that non-physical work environment does not significantly influence employee retention.

Implications PT. Senyum Media Utama Jember can maintain a work environment that is already good. Companies can also add lighting in shops, air conditioning plus, and also the comfort of the working environment. This is done to reduce the boredom and fatigue of employees at work.

\section{Effect of Satisfaction on Employee Retention at the Office of PT. Senyum Media Utama Jember}

The results show that satisfaction variables significant positive effect on employee satisfaction in PT. Senyum Media Utama Jember, with a significance value less than 0.05 is 0.003 . So the seventh hypothesis which states that job satisfaction is a significant direct effect on the retention of employees of PT. Senyum Media Utama Jember, is accepted. This indicates that the better the satisfaction felt by employees, the higher the retention of employees.

Job satisfaction is an important thing to be considered by the company, it was based on three reasons as proposed by Spector (2003): First, job satisfaction can be a measuring tool effectiveness of measures taken by the company to the employee. Second, job satisfaction affects employee behavior that ultimately affect the smooth running of the company. Third, job satisfaction is an indicator of problems in the company because of the low level of job satisfaction showed irregularities in the department. Oktina, et al (2018), found that job satisfaction significantly influence employee retention.

The results showed that employees of PT. Senyum Media Utama Jember feel satisfied because:

a. Jobs PT. Senyum Media Utama Jember.

b. Salary given.

c. Their promotion

d. Coworker family.

The implication is PT. Senyum Media Utama Jember can sustain these efforts already implemented forms of attention and also be improved by more sensitive to the needs of employees so that employees feel comfortable and satisfied and can last longer in the company. The company is also expected to enrich the knowledge of its employees by providing training on a periodic basis.

\section{Effect of Compensation on Employee Retention through Job Satisfaction at the Office of PT. Senyum Media Utama Jember}

The test results showed that the variable compensation effect on employee retention through job satisfaction. So the eighth hypothesis which states that compensation significant indirect effect on the retention of employees through the job satisfaction of employees of PT. Senyum Media Utama Jember, is accepted. This indicates that the better the compensation given by the company to its employees, then it can stimulate 
employment and employee satisfaction. Due to appropriate compensation gained from working will affect the job satisfaction of employees, so that employees will feel comfortable to work at. Smile Media Utama Jember.

The analysis showed that job satisfaction is able to mediate the effect of compensation on the retention, although not as a direct influence. Salaries, THR, target bonus, periodic salary increases, overtime, BPJS Kesehatan, BPJS Ketenagakerjaan, the annual tourist each year end, maternity leave and annual leave to employees, many employees feel satisfied and feel at home working in PT. Senyum Media Utama Jember.

\section{Effect of Organizational Commitment on Employee Retention Through Job Satisfaction in the Office of PT. Senyum Media Utama Jember}

The test results showed that the variables of organizational commitment influence on employee retention through job satisfaction. So the ninth hypothesis which states that an indirect effect of organizational commitment significantly influence employee retention through job satisfaction of employees of PT. Senyum Media Utama Jember, is accepted. The results showed that satisfaction is able to mediate the organizational commitment in influencing retention.

According Ivancevich et al., (2012: 34), organizational commitment is a feeling of identification, engagement and loyalty expressed by the employees of the company. Organizational commitment is the desire and the confidence level of an employee to be a member of the organization and receive the goals of the organization or an attitude where employees are tied to the organization or company and familiar with the organization where he works.

The significant variables organizational commitment to employee satisfaction at PT. Senyum Media Utama Jember evidenced by the number of employees who admit that the company has an emotional bond with their employees, PT. Senyum Media Utama Jember is the workplace that can bring benefits for employees and PT. Senyum Media Utama Jember is a workplace that appreciates the loyalty of its employees. With the commitment oraganisasional owned by the company, the employees have positive feelings about the company and in the end they survived longer works at the company.

Effect of Work Environment on Employee Retention Through Job Satisfaction in the Office of PT. Senyum Media Utama Jember

The test results showed that the work environment influence on retention through job satisfaction. So the tenth hypothesis which states that the work environment is not directly significant effect on the retention of employees through the job satisfaction of employees of PT. Senyum Media Utama Jember, is accepted. Supportive work environment will affect job satisfaction and employee morale in a job done, so PT. Senyum Media Utama Jember must see to it that factors including the work environment can be cultivated in such a way and have a positive influence.

Baron and Rue (2007: 321) states that a good working environment will provide comfort and raise employee morale so that they can do the tasks well. In the end, the work environment can increase job satisfaction in the work. The analysis showed that the working environment PT. Senyum Media Utama Jember very feasible, have a place of worship for the employees, has a special room for rest of employees, have a special parking lot employee, PT. Senyum Media Utama Jember provide office facilities for employee vehicles, PT. Senyum Media Utama Jember safe, comfortable, PT. Senyum Media Utama Jember provide training to its employees, and has a sense of family, and always given a religious spirit. With the excellent working environment such that employees are satisfied and last worked at PT. Senyum Media Utama Jember. The results also showed that employees of PT. Senyum Media Utama Jember feel satisfied because jobs PT. Senyum Media Utama Jember, salaries are given, their promotion and co-workers that kinship. Employees are satisfied and ultimately loyal to the company. Satisfaction they feel their impact on the viability of the company.

\section{Conclusion}

Based on the analysis and discussion of the study results, it can be some conclusions as follows:

a. Compensation has a significant positive effect on employee satisfaction in PT. Senyum Media Utama Jember. PT. Senyum Media Utama Jember has given salary regularly, THR, target bonus, salary increase periodically, overtime, engage employees in BPJS, BPJS Ketenagakerjaan, the annual tourist 
each year end, maternity leave for employees who give birth, and annual leave so employees feel satisfaction in their work.

b. Organizational commitment has a significant positive effect on employee satisfaction in PT. Senyum Media Utama Jember. Employees feel satisfied because PT. Senyum Media Utama Jember have an emotional bond with their employees, PT. Senyum Media Utama Jember is the workplace that can bring benefits for employees, and a workplace that appreciates the loyalty of its employees.

c. Work environment has a significant positive effect on employee satisfaction in PT. Senyum Media Utama Jember. The satisfaction felt by employees due to the location of PT. Senyum Media Utama Jember is worthy, PT. Senyum Media Utama Jember have a place of worship for the employees, has a special room for rest of employees, have a special parking lot employee, PT. Senyum Media Utama Jember provide office facilities for employee vehicles, PT. Senyum Media Utama Jember safe, comfortable, PT. Senyum Media Utama Jember provide training to employees, PT. Senyum Media Utama Jember have a sense of family, and always given a religious spirit.

d. Compensation significant has a positive effect on retention of employees at PT. Senyum Media Utama Jember. The persistence of the employees in the company, due to PT. Senyum Media Utama Jember work culture have a positive impact, the company provides training to develop the potential of the company appreciated the achievements of its employees, the nature of flexible work and the relationship between employees and leadership intertwined harmoniously.

e. Organizational commitment has a significant positive effect on retention of employees at PT. Senyum Media Utama Jember. The majority of employees feel that PT. Senyum Media Utama Jember have an emotional bond with its employees, the company generates revenue for its employees, and a workplace that appreciates the loyalty of its employees, thereby increasing their retention.

f. Environmentally has a significant positive effect on retention of employees at PT. Senyum Media Utama Jember. Significant positive working environment on the retention of employees of PT. Senyum Media Utama Jember evidenced by the number of employees who have recognized that: the location of PT. Main Media Jember decent smile, PT. Senyum Media Utama Jember have a place of worship for the employees, there is a special room for rest of employees, there is a parking particular employees, the company provides transport facilities office for employees, a working environment that is safe, comfortable, companies provide training to their employees, there is a sense of family, and companies always given a religious spirit so employees work in the company survive.

g. Satisfaction has a significant positive effect on employee satisfaction in PT. Senyum Media Utama Jember. Employees PT. Senyum Media Utama Jember feel satisfied because jobs PT. Senyum Media Utama Jember, salaries are given, their promotion and co-workers that kinship.

h. Compensation has a significant indirect effect on the retention of employees through the job satisfaction of employees of PT. Senyum Media Utama Jember analysis showed that job satisfaction is able to mediate the effect of compensation on the retention, although not as a direct influence. Salaries, THR, target bonus, periodic salary increases, overtime, BPJS Kesehatan, BPJS Ketenagakerjaan, the annual tourist each year end, maternity leave and annual leave to employees, many employees feel satisfied and feel at home working in PT. Senyum Media Utama Jember.

i. Organizational commitment has a significant indirect effect on the retention of employees through the job satisfaction of employees of PT. Senyum Media Utama Jember. Employees who admitted that the company has an emotional bond with their employees, PT. Senyum Media Utama Jember is the workplace that can bring benefits for employees and PT. Senyum Media Utama Jember is a workplace that appreciates the loyalty of its employees. With the commitment oraganisasional owned by the company, the employees have positive feelings about the company and in the end they survived longer works at the company.

j. Work environment has a significant indirect effect on the retention of employees through the job satisfaction of employees of PT. Senyum Media Utama Jember. PT work environment. Smile Media Utama Jember very decent. PT. Senyum Media Utama Jember have a place of worship for the employees, has a special room for rest of employees, have a special parking lot employee, PT. Senyum 
Media Utama Jember provide office facilities for employee vehicles, PT. Senyum Media Utama Jember safe, comfortable, PT. Senyum Media Utama Jember provide training to its employees, and has a sense of family, and always given a religious spirit. With the excellent working environment such that employees are satisfied and last worked at PT. Senyum Media Utama Jember.

\section{References}

[1.] Anshori, Syaiful. 2018. Pengaruh Kompensasi dan Lingkungan Kerja Non Fisik Terhadap Retensi Karyawan di Badan Amil Zakat Nasional Propinsi Jawa Timur.

[2.] Baron, L.L., dan Rue, L.W. 2007. Human Resource Management: Global Strategies for Managing A Diverse Workforce. New Jesey: Prentice Hall Inc.

[3.] Davis, Keith dan John Newstrom. 2004. Perilaku Dalam Organisasi. Edisi Ketujuh. Jakarta. Erlangga

[4.] Dhermawan, Anak Agung Ngurah Bagus; I Gede Adnyana Sudibya dan I Wayan Mudiartha Utama. 2012. Pengaruh Motivasi, Lingkungan Kerja, Kompetensi dan Kompensasi Terhadap Kepuasan kerja dan Kinerja Pegawai di Lingkungan Kantor Dinas Pekerjaan Umum Provinsi Bali. Jurnal Manajemen, Strategi Bisnis dan Kewirausahaan, Vol. 6

[5.] Fathonah Siti dan Ida Utami. 2011. Pengaruh Kompensasi, Pengembangan Karir, Lingkungan Kerjadan Komitmen organisasional terhadap Kepuasan kerja Pegawai Sekretariat Daerah Kabupaten Karanganyar dengan Keyakinan Diri (Self Efficacy) sebagai Variabel Pemoderasi. EJournal STIAUB Surakarta Vol 1 No 1

[6.] Hariandja, Marihot T.E, 2002. Manajemen Sumber Daya Manusia. Jakarta: Grasindo

[7.] Holbeche, L. 2005. The High Performance Organization: Creating Dynamic Stability and Suistanable Success. Oxford: Elseiver Butterworth-Heinnemann.

[8.] Ivancevich, John M, Robert Konopaske dan Michael T Matteso, 2012. Perilaku dan Manajemen Organisasi, Edisi Ketujuh, Erlangga, Jakarta

[9.] Kumar, G. Amruth and Singh, Jayprakash dan. 2012, Relationship Between Teaching Competence And Job Satisfaction: A Study Among Teacher Educators Working in Self-Financing Colleges in Uttar Pradesh. Indian Journal of Applied Research Volume : 3 | Issue : 5 | May 2013 | ISSN 2249-555X

[10.] Luthans, F. 2011. Organizational Behavior. 8 th edition. New York: The McGraw-Hill Co., Inc

[11.] Mathis, Robert L. dan Jackson, John H, 2006. Human Resource Management. Tenth Edition. Salemba Empat, Jakarta

[12.] Nugroho., dan Kunartinah. 2012. Analisis Pengaruh Kompensasi dan Pengembangan Karier terhadap Kepuasan kerja dengan Mediasi Motivasi Kerja. Jurnal Bisnis dan Ekonomi. Vol.19, No.2.

[13.] Oktina dkk. 2015. Pengaruh Kompensasi, Lingkungan Kerja Dan Desain Tugas Terhadap Kepuasan kerja Dan Dampaknya Terhadap Retensi Karyawan Palang Merah Indonesia (PMI) Provinsi Aceh. Jurnal Manajemen. Volume 4. Nomor 1.

[14.] Plangiten, Pegi. 2013. Gaya Kepemimpinan dan Lingkungan Kerja Pengaruhnya Terhadap Kepuasan kerja Karyawan Pada PT. Pos Indonesia (Persero) Manado. Jurnal EMBA Vol 1 No-4

[15.] Putra Swambawa dan Agoes Ganesha. 2018. Pengaruh Kompensasi, Lingkungan Kerja Dan Perceived Organizational Support (POS) terhadap retensi karyawan. E-Jurnal Manajemen Unud, Vol. 5, No. 2, 2016: 810-837

[16.] Ratnasari, Eka. 2011. Analisis Kinerja Rumah Sakit Kusta Sumberglagah Mojokerto Dengan Metode Balanced Scorecard Perspektif Pembelajaran dan Pertumbuhan. Jurnal Ekonomi dan Bisnis, Vol. 6, No. 1 Hal. 89-110

[17.] Robbins, P.Stephen dan Timothy A. Judge. 2012. Perilaku Organisasi. Salemba Empat. Jakarta

[18.] Roodt, G. 2013. The validation of the turnover intention scale. SA Journal of Human Resource Management, 11(1), 507-519.

[19.] Ruky, 2001. Sistem Manajemen Kinerja. PT Gramedia, Jakarta.

[20.] Schultz, D. dan Schultz, E. S. 2010. Psychology and work today (10 edition). New York: Pearson.

[21.] Shannock, Linda, dan Rhoades, Eisenberger Robeert. 2016. When Supervisor Feel supported : Relationship With Subordinates' Perceived Supervisor Support, Perceived Organizational Support and Performance, Journal of Applied Psychology, Vol. 91,. No. 3,689-695. 
[22.] Spector, Paul E. 2003. Industrial and Organizational Psychology, 3rd Ed. John WileydanSons, New York.

[23.] Trisnaningsih. 2001. Pengaruh Komitmen Terhadap Kepuasan kerja Auditor : Motivasi Sebagai Variabel Intervening (Studi Empiris Pda KAP di Jawa Timur).” UNDIP, Semarang 